\title{
A New Simple Method for the Preparation of Calcium Ion Selective Electrode and its Analytical Applications $\dagger$
}

\author{
A. VIJAYALAKSHMI ${ }^{*}$ and J. THAMARAI SELVI \\ Department of Chemistry, Avinashilingam Institute for Home Science \\ and Higher Education for Women, Coimbatore- 641043, Tamilnadu, India \\ vijayalakshmi.chemist@gmail.com
}

Received 10 January 2013 / Accepted 15 February 2013

\begin{abstract}
A new, efficient calcium ion selective electrode has been prepared using mono ester and polyvinyl chloride. The electrode showed Nernstian response in the concentration range of $1 \mathrm{M}$ to $1 \times 10^{-4} \mathrm{M}$ with detection limits in the order of $10^{-4} \mathrm{M}$. The stable potentiometric signals are obtained within a short time period of $1 \mathrm{~min}$. The effect of $\mathrm{pH}$ and the effect of medium have been studied and found to give a better response. Selective coefficient values were evaluated using fixed interference method. The sensor was applied as an indicator electrode for potentiometric titrations of $\mathrm{Ca}(\mathrm{II})$ ions with EDTA and also for the determination of calcium in milk and water samples.
\end{abstract}

Keywords: Calcium, Ion selective electrode, Nernstian response, Potentiometry, Polyvinyl chloride

\section{Introduction}

Calcium is an essential nutrient in plants. It plays a significant structural role in the cell wall and membrane; as a counter -cation for inorganic and organic anions; as a main intracellular messenger and helps to harvest and process nitrates for protein metabolism ${ }^{1}$.

Ion-selective electrode (ISE) is a kind of potentiometric sensor which has become increasingly important in the electrochemical analysis system. The analysis technology of ISE is based on the relationship between electrode potential and ion activity so as to perform a detection of ions. There are several advantages such as high selectivity, high sensitivity, quick analysis, low cost, wide variety of tested ions, and little sample size in this technology ${ }^{2,3}$.

Ion-selective membrane is the key component of an ion-selective electrode. Poly(vinyl chloride) (PVC) is generally chosen as the preferred polymeric base for ion-selective membranes ${ }^{4,5}$.Today, many techniques have been used for the samarium determination such as inductive coupled plasma atomic emission spectroscopy (ICP-AES), cathode-ray-excited emission spectroscopy and laser-excited atomic fluorescence spectrometry ${ }^{6}$. However, the utility of ion-selective electrodes (ISEs) is being increasingly realized by analytical chemists in view of the rapid growth of industry and technology all over the world, as they represent a rapid, accurate and low-cost method of analysis ${ }^{7-11}$. 
The potentiometric method is nondestructive and it means that tested samples can be used in the future ${ }^{12}$. In recent years direct potentiometry has become important as an analytical tool largely. It is a method that uses electrodes to measure potential differences that provide chemical information of the species in solution .Studies of potentiometric sensors or so - called ISEs have been subject of continuous efforts ${ }^{13}$.

The basic idea of the present study is to utilize ester compound as an electro active material, Dibutyl phthalate (DBP) as the plasticizer, sodium tetraphenylborate (NaTBP) as anion excluder and PVC as membrane matrix for a new calcium ion selective electrode.

\section{Experimental}

Polyvinyl chloride (PVC), dioctyl phthalate (DOP) and sodium tetraphenylborate (NATBP), tetrahydrofuran (THF) were obtained from E. Merck. All other reagents such as calcium chloride $\left(\mathrm{CaCl}_{2}\right)$, magnesium chloride $\left(\mathrm{MgCl}_{2}\right)$ and sodium chloride $(\mathrm{NaCl})$ were of analytical grade. The standard stock solutions $\left(1 \mathrm{M} \mathrm{CaCl}_{2}\right)$ were prepared using distilled water. Working solutions were made by dilution of the stock solution. A digjtal potentiometer (EQUIP - TRONICS EQ 602) with $\mathrm{Ag} / \mathrm{AgCl}$ electrode as a reference electrode were used for this study.

\section{Preparation of heterogeneous precipitate for ion selective electrode}

$10 \mathrm{~g}$ of Cinnamic acid was taken in a RB flask. $35 \mathrm{~mL}$ of methanol and $4 \mathrm{~mL}$ of conc. $\mathrm{H}_{2} \mathrm{SO}_{4}$ was added to cinnamic acid. It was attached into an air condenser and refluxed for 3 hours. The solution was cooled and added into crushed ice in a beaker. The obtained precipitate was filtered and washed with sodium carbonate solution and cold water. The precipitate was dried and powdered. It was recrystallized from methanol.

\section{Preparation of membrane ion selective electrode}

Varying amounts of heterogeneous precipitate were taken to prepare the ion selective membranes. 0.1, 0.2, $0.3 \mathrm{~g}$ of precipitate along with $0.1 \mathrm{~g}$ of PVC, DOP and NaTPB was dissolved in $3 \mathrm{~mL}$ THF and the clear solution was evaporated slowly. Then it was mixed with araldite and spread uniformly over Whatman filter paper No.42 to attain $0.9 \mathrm{~mm}$ thicknesses of the electroactive membrane. The membrane was air dried for $48 \mathrm{~h}$.

A circular piece from each of the membrane was cut and fixed with resin at one end of hollow glass tubes of diameter $2 \mathrm{~cm}$ and length $10 \mathrm{~cm}$. The tubes were filled with $1 \mathrm{M}$ solution of calcium chloride. Reference copper metal wire of diameter $0.5 \mathrm{~mm}$ and length $12 \mathrm{~cm}$ was inserted through the other end of tube in such a way, that it remains dipped in the $1 \mathrm{M}$ solution of calcium chloride. The electrodes were conditioned for 48 hours to attain equilibrium in $1 \mathrm{M} \mathrm{CaCl}_{2}$ solution. The EMF measurements were carried out using the following cell assembly,

\begin{tabular}{|c|c|c|c|c|}
$\begin{array}{c}\text { Internal reference } \\
\text { Electrode } \\
(\mathrm{Cu} \text { wire })\end{array}$ & $\begin{array}{c}\text { Internal reference } \\
\text { solution } \mathrm{CaCl}_{2}\end{array}$ & $\begin{array}{c}\text { Electro active } \\
\text { membrane }\end{array}$ & $\begin{array}{c}\text { Sample } \\
\text { solution }\end{array}$ & $\begin{array}{c}\text { External } \\
\text { reference } \\
\text { electrode (SCE) }\end{array}$
\end{tabular}

\section{Results and Discussion}

The electrode was first conditioned in $1 \mathrm{M} \mathrm{CaCl}_{2}$ solution to attain stable equilibrium. In order to test the performance of the electrode, various parameters including response time, selectivity, the influence of $\mathrm{pH}$, influence of medium and the membrane composition on the response of the electrode were investigated. 


\section{Optimization of membrane composition}

It is well known that the sensitivity and selectivity of the ion-selective sensors not only depend on the nature of ionophore, but also significantly on the membrane composition and the properties of plasticizers and anion excluder used ${ }^{14-15}$. Thus, the influence of the membrane composition, the nature and amount of amount of methyl cinnamate and amount of plasticizers and amount of exclude on the potential response of the $\mathrm{Ca}$ (II) sensor were investigated.

For this purpose, the parameters like measurement range and response time were compared for the three electrodes. Electrode containing $0.3 \mathrm{~g}$ of precipitate was selected for further studies, since it has a small response time and is highly stable. The details are given in Table 1.

Table 1. Optimization of membrane composition

\begin{tabular}{cclcc}
\hline $\begin{array}{c}\text { Electrode } \\
\text { number }\end{array}$ & $\begin{array}{c}\text { Methyl cinnamate } \\
\mathrm{g}\end{array}$ & Binder & $\begin{array}{c}\text { Measurement } \\
\text { Range }\end{array}$ & $\begin{array}{c}\text { Response } \\
\text { time }\end{array}$ \\
\hline 1 & 0.2 & Araldite & $1 \times 10^{-4}-1 \mathrm{M}$ & $3 \mathrm{~min}$ \\
2 & 0.3 & Araldite & $1 \times 10^{-4}-1 \mathrm{M}$ & $1 \mathrm{~min}$ \\
3 & 0.4 & Araldite & $1 \times 10^{-4}-1 \mathrm{M}$ & $3 \mathrm{~min}$ \\
\hline
\end{tabular}

\section{Response time}

The response time is an important factor for ion selective electrodes. In the present study, the practical response time was recorded over a $\mathrm{Ca}$ (II) cation concentration range of $1 \mathrm{M}-10^{-4} \mathrm{M}$ and throughout the entire concentration range, the electrode reached equilibrium within a short period of $1 \mathrm{~min}$.

Table 2. Electrode response for $\mathrm{Ca}^{2+}$ ions

\begin{tabular}{ccc}
\hline S.No & Concentration of $\mathrm{CaCl}_{2}$ solution, $\mathrm{M}$ & EMF, volts \\
\hline 1 & 1 & 0.158 \\
2 & $1 \times 10^{-1}$ & 0.127 \\
3 & $1 \times 10^{-2}$ & 0.099 \\
4 & $1 \times 10^{-3}$ & 0.070 \\
5 & $1 \times 10^{-4}$ & 0.036 \\
6 & $1 \times 10^{-5}$ & 0.036 \\
\hline
\end{tabular}

\section{Electrode response}

Standard Electrode potential $\left(\mathrm{E}^{0}\right)$ determined by extrapolation method was found to be $0.159 \mathrm{~V}$. The slope value was found to be $30 \mathrm{mV} / \mathrm{dec}$ ade. This shows that the electrode behaves according to Nernst equation (Figure 1).

\section{Effect of $p H$}

To study the effect of $\mathrm{pH}$, a standard solution containing $1 \mathrm{M} \mathrm{CaCl}_{2}$ ion were prepared in which a series of buffer solution was added. It was found that the potential remained unchanged with in the $\mathrm{pH}$ range of 1 to 6 which is found to be the working $\mathrm{pH}$ range for the electrode. At higher $\mathrm{pH}$, the deviation can be assigned because of the formation of $\mathrm{Ca}(\mathrm{OH})_{2}$ precipitates $^{16}$.

\section{Effect of medium}

To study the effect of medium, a standard solution containing $1 \mathrm{M} \mathrm{CaCl}_{2}$ ion in a series of 25,50 and $75 \%$, ethanol, acetone and dimethyl formamide, dimethyl acetamide was added. It was found that the potential remained unchanged in the above medium. 


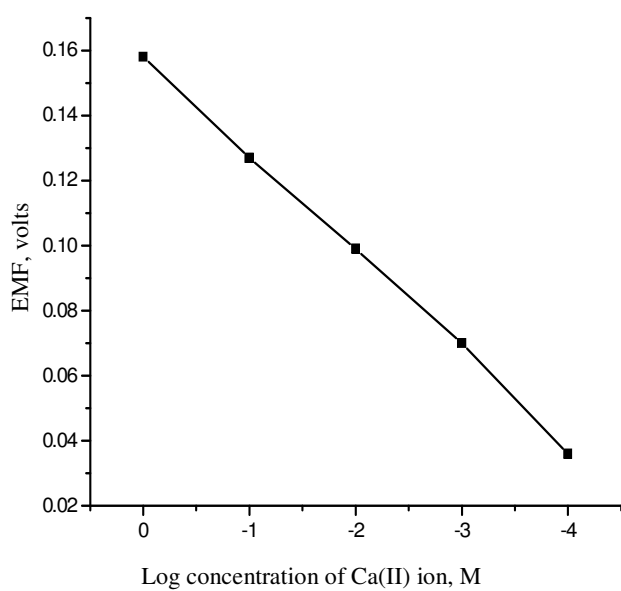

Figure 1. Plot of log concentration of $\mathrm{Ca}(\mathrm{II})$ ion vs. EMF

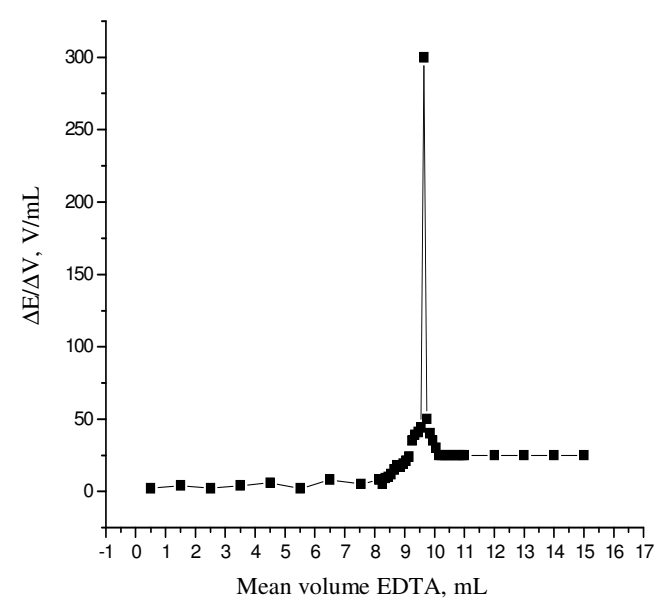

Figure 2. Plot of $\Delta \mathrm{E} / \Delta \mathrm{V}$ (volts $/ \mathrm{mL}) \quad v s$. mean volume of EDTA, $\mathrm{mL}$

\section{Interference study}

Selectivity is one of the most important characteristics of a chemical sensor. The influence of interfering ion on the response behavior of ion selective electrode is usually described in terms of selectivity coefficient. The potential response of the calcium ion sensor to different ions have been investigated by determining the selectivity coefficient of the electrode using Fixed Interference method (FIM) based on semi empirical Nicolskii-Eisenman equation and the concentration of interfering ions was set to $1 \mathrm{M}$. It was found that the potential remains unaffected in the presence of a series of various cations like $\mathrm{Na}^{+}, \mathrm{Mg}^{2+}, \mathrm{Co}^{2+}, \mathrm{Sr}^{2+} \mathrm{K}^{+}$, $\mathrm{Mn}^{2+}$ and anions like $\mathrm{I}^{-}, \mathrm{Br}^{-}, \mathrm{No}^{3-}$ and $\mathrm{Cl}^{-}$.

\section{Analytical applications}

The $\mathrm{Ca}(\mathrm{II})$ sensor was used as an indicator electrode in the potentiometric titration of $\mathrm{Ca}$ (II) with EDTA. $25 \mathrm{~mL}$ of $1 \mathrm{M}$ solution of $\mathrm{Ca}$ (II) was titrated with $0.1 \mathrm{M}$ EDTA solution. Before the end point, the potential shows usual logarithmic change with the volume of the titrant added while the potential response after the end point remains almost constant (Figure 2).

To assess the applicability of the sensor to real samples, an attempt was made to determine calcium ion in real samples like milk, water samples. The recovery of calcium ion in sample analysis was found to be quantitative with the maximum recovery of $97 \%$.

\section{Conclusion}

The sensor exhibited good reproducibility over a useful lifetime of 3 months. This electrode is superior to the existing electrodes with regard to the slope, $\mathrm{pH}$ range, response time and selectivity over a number of cations and anions. The high selectivity of the proposed sensor made it possible to determine the calcium in different milk, water samples and was also successfully used as an indicator electrode in potentiometric titration of $\mathrm{Ca}^{2+}$ ions with EDTA.

\section{Acknowledgement}

The authors thank Avinashilingam Institute for Home Science and Higher Education for Women, Coimbatore for providing necessary facilities to carry out study. 


\section{References}

1. Caceres E, Garcia M L and Selgas M D, Meat Sci., 2006, 73, 368-377.

2. Ganjali M R, Norouzi P, Faridbod F, Rezapour M and Pourjavid M R, J Iran Chem Soc., 2007, 4(1), 1-29.

3. Rzewuska A, Wojciechowski M, Bulska E, Hall E A H, Maksymiuk K and Michalska A, Anal Chem., 2008, 80(1), 321-327.

4. Cha G S, Liu D, Meyerhoff M E, Cantor H C, Midgley A R, Goldberg H D and Brown R B, Anal Chem., 1991, 63,1666-1672.

5. Ammann D, Morf W E, Anker P, Pretsch E, Meier P and Simon W, Ion-Selective Electrode Rev., 1983, 3, 3-92.

6. Morakot N, Ngeontae W, Aeungmaitrepirom W and Tuntulani T, Bull Korean Chem., Soc., 2008, 29(1), 221-224.

7. Faridbod F, Ganjali M R, Dinarvand R and Norouzi P, Combinatorial Chemistry \& High Throughput Screening, 2007, 10, 527-546.

8. Faridbod F, Ganjali M R and Norouzi P, Sensors, 2008, 8, 1645-1703.

9. Harris D C, "Quantitative Chemical Analysis Edition, Newyork, 1998, 375.

10. Faridbod F, Ganjali M R, Dinarvand R and Norouzi P, African J Biotechnol., 2007, 6(25), 2960-2987.

11. Javanbakht M, Ganjali M R, Norouzi P, Abdouss M and Riahi S, Anal Lett., 2008, 41, 619 .

12. Mentus S, Elektrohemija (Electrochemistry), Fakultet za Fizicku Hemiju, Beograd, 1999.

13. El-Ragheh N A, Kosasy A M, Abbas S S and El-Khateeb S Z, Anal Cham Acta, 2000, 418, 93.

14. Shamsipur M, Yousefi M and Ganjali M R, Anal Chem., 2000, 72(11), 2391-2394.

15. Sheen S R and Shih J S, Analyst, 1992, 117, 1691-1695.

16. Ashok Kumar and Mittal S K, Sensors Actuators B: Chem., 2004, 99, 340-343. 